\title{
OSTEOCALCIN GENE POLYMORPHISM IN INDONESIAN MEN WITH PERIODONTITIS
}

\author{
NAMIRA KAULIKA ${ }^{1}$, TALITHA ALWASRIS ${ }^{1}$, NINIARTI DJAMAL ${ }^{1}$, BENSO SULIJAYA ${ }^{2}$, CHRISTOPHER TALBOT ${ }^{3}$, \\ ELZA IBRAHIM AUERKARI ${ }^{1 *}$
}

${ }^{1}$ Department of Oral Biology, Faculty of Dentistry, Universitas Indonesia, Jakarta 10430, Indonesia. ${ }^{2}$ Department of Periodontics, Faculty of Dentistry, Universitas Indonesia, Jakarta 10430, Indonesia. ${ }^{3}$ Department of Human Genetics, Leicester University, Leicester, UK.

Email: eiauerkari@yahoo.com

Received: 26 September 2019, Revised and Accepted: 24 December 2019

ABSTRACT

Objective: Through this work, we aimed to clarify the association between the severity of periodontitis and osteocalcin (OC) gene C298T polymorphism in Indonesian male subjects.

Methods: DNA was extracted from blood serum samples of 100 consenting Indonesian men whose periodontitis was classified as mild, moderate, or severe. Polymerase chain reaction and restriction fragment length polymorphism techniques were applied to evaluate the status of OC (C298T) polymorphism using HindIII restriction enzyme and electrophoresis in agarose gel to separate the indicated fragments.

Results: Although genotype distribution of the OC C298T polymorphism showed a trend for more frequent occurrence of genotype hh (and allele h) with increasing severity of periodontitis, this trend was not statistically significant in the tested sample population, in whom the HH genotype appeared to be relatively rare.

Conclusion: The results showed no significant association between the severity of periodontitis and OC C298T polymorphism in Indonesian male subjects.

Keywords: Osteocalcin, Gene polymorphism, Periodontitis.

(c) 2020 The Authors. Published by Innovare Academic Sciences Pvt Ltd. This is an open access article under the CC BY license (http://creativecommons. org/licenses/by/4. 0/) DOI: http://dx.doi.org/10.22159/ijap.2020.v12s1.ARL028

\section{INTRODUCTION}

Periodontitis, a complex multifactorial disease, has a high global prevalence, including in Indonesia. According to the Indonesian national survey on domestic health 2003, dental and oral diseases were ranked first in the 10 most common disease groups affecting individuals; of all dental and oral diseases, periodontal disease was the most common complaint following caries. The survey for the following year (SKRT 2004) indicated a prevalence of $96.6 \%$ for periodontal disease [1]. We have reported previously that chronic periodontitis occurred frequently in all age groups and increased in the older age such as 56\% in the adolescent group, 74\% in the adult group, and $88 \%$ in the elderly group [2]. In America, $95 \%$ of the $>65$-year-old population has experienced periodontal attachment loss in at least one side of their mouth. In addition, men have higher levels of periodontal destruction than do women among all age groups [3].

Periodontitis is an inflammatory condition of the gum tissue surrounding the teeth and is caused by microorganisms, resulting in progressive destruction of the periodontal ligament and alveolar bone, with or without pocket formation, recession, or both. Clinical attachment loss is a sign of periodontal disease [4]. According to the American Academy of Periodontology, periodontal severity is divided into three categories based on clinical attachment loss: Mild (1-2 mm), moderate (3-4 $\mathrm{mm})$, and severe ( $>5 \mathrm{~mm}$ ) [5].

It is known that heredity is a susceptibility factor affecting the periodontal condition. Reportedly, individuals with a polymorphism in the interleukin-1 gene are susceptible to periodontitis, showing faster onset, more bone destruction, and more severe inflammation when exposed to dental plaque [6].

Bone gamma-carboxyglutamate (Gla) protein, also known as osteocalcin $(\mathrm{OC})$, is the most common non-collagenous protein in bone. OC plays an important role in bone metabolism and is used as a clinical marker in bone remodeling [7-9]. Moreover, it functions as a negative regulator of bone formation [10]. The OC protein is encoded by the OC gene that instructs osteoblasts to synthesize OC protein. Polymorphism in the promoter region of this gene is considered to be associated with bone mineral density (BMD) [8].

The association between BMD and periodontal disease has been reported with varying results. In particular, a significant association has been suggested between periodontal disease and single nucleotide polymorphisms in certain genes known to play an important role in BMD [9]. In this study, we aimed to determine the distribution of the OC C298T polymorphism and to clarify its relationship with periodontal severity in an Indonesian male population.

\section{METHODS}

Venous blood samples were collected from 100 consenting Indonesian males with periodontitis of varying degrees of severity as evaluated by a periodontist. DNA was extracted from the samples using techniques previously described $[11,12]$ and stored at $-20^{\circ} \mathrm{C}$.

According to the severity of periodontitis, the subjects were grouped into classes of mild $(\mathrm{n}=10)$, moderate $(\mathrm{n}=48)$, and severe $(n=42)$ periodontitis. From the extracted DNA, a 253-bp fragment was amplified by polymerase chain reaction (PCR, Fig. 1) with the forward primer $5^{\prime}$-CCGCAGCTCCCAACCACAA TAAGCT-3' and reverse primer 5'-CAATAGGGCGAGGAGT-3'. Accordingly, $1 \mathrm{~mL}$ of genomic DNA was used for PCR amplification in a reaction mixture containing $10 \mu \mathrm{L}$ KAPA $2 \mathrm{G}^{\mathrm{TM}}$ Fast ReadyMix $(2 \times)$ and $2 \mu \mathrm{L}$ of each primer. The reactions were performed in a Bio-Rad thermocycler and comprised the initial denaturation at $95^{\circ} \mathrm{C}$ for $5 \mathrm{~min}$, followed by 35 cycles of denaturation at $95^{\circ} \mathrm{C}$ for $30 \mathrm{~s}$, annealing at $60^{\circ} \mathrm{C}$ for $30 \mathrm{~s}$, and 
elongation at $72^{\circ} \mathrm{C}$ for $30 \mathrm{~s}$, with a final extension at $72^{\circ} \mathrm{C}$ for $7 \mathrm{~min}$. The restriction fragment length polymorphism (RFLP) technique was performed in a final reaction volume of $10 \mu \mathrm{L}$ using $0.1 \mu \mathrm{L}$ of HindIII $\left(5^{\prime}\right.$... A'AGCTT ... $\left.3^{\prime}\right)$ and aliquots of PCR products digested at $37^{\circ} \mathrm{C}$ for $4 \mathrm{~h}$. Further, the digested products were separated by $3 \%$ agarose gel electrophoresis mixed with $2 \mu \mathrm{L}$ GelRed $^{\mathrm{TM}}$ Nucleic Acid Gel Stain 10,000x in water. Genotypes were determined by comparing the RFLP band patterns with 25-bp DNA ladder. The RFLP is formed by a single base transition $\mathrm{C}$ to $\mathrm{T}$ of the OC gene at the HindIII restriction site, which recognizes the mutant allele. The alleles with HindIII restriction site were designated " $h$ " with two fragments of 232 and $21 \mathrm{bp}$ in size, and those without the HindIII restriction site were designated " $\mathrm{H}$ " with one fragment of $253 \mathrm{bp}$ in size (Figs. 1 and 2).

\section{RESULTS}

Table 1 shows the distributions of genotypes and allotypes of the OC C298T polymorphism in all 100 male subjects. The hh genotype $(69 \%)$ was observed to be dominant and $\mathrm{HH}$ was rare $(1 \%)$, with corresponding dominance of the $\mathrm{h}$ allele (84\%). Table 2 shows distribution of genotypes according to the severity of periodontitis. The hh genotype appears to be more frequent with increasing severity of periodontitis, with a corresponding decrease in the Hh genotype frequency. The only observed case of genotype $\mathrm{HH}$ occurred in a subject with moderate periodontitis. Distribution of alleles according to the severity of periodontitis is presented in Table 3 , with the maximum frequency of the $\mathrm{h}$ allele (89.3\%) coinciding with severe periodontitis.

\section{DISCUSSION}

In this study, we identified the distribution of the OC C298T polymorphism of the OC gene in Indonesian male subjects with periodontitis. Although the results appear to suggest a trend for a higher frequency of the hh genotype (and h allele) with increasing severity of periodontitis, the trend was not statistically significant. In total, $50 \%$ of the subjects with mild periodontitis had the hh genotype, whereas $>76.8 \%$ of the subjects with severe periodontitis had this genotype. In principle, this could suggest some oral health benefits carried by the

Table 1: Genotype and allotype distribution of the subjects

\begin{tabular}{llllllllll}
\hline & \multicolumn{3}{c}{ Genotypes } & \multicolumn{3}{c}{ Alleles } \\
\cline { 2 - 4 } & hh & Hh & HH & Total & & h & H & Total \\
\hline Number & 69 & 30 & 1 & 100 & & 168 & 32 & 200 \\
Frequency (\%) & 69 & 30 & 1 & 100 & & 84 & 16 & 100 \\
\hline
\end{tabular}

Table 2: Distribution of genotypes according to the severity of periodontitis

\begin{tabular}{|c|c|c|c|c|c|c|}
\hline \multirow[t]{3}{*}{ Genotype } & \multicolumn{6}{|c|}{ Severity } \\
\hline & \multicolumn{2}{|r|}{ Mild } & \multicolumn{2}{|c|}{ Moderate } & \multicolumn{2}{|r|}{ Severe } \\
\hline & No. & Percentage & No. & Percentage & No. & Percentage \\
\hline hh & 5 & 50.0 & 31 & 64.6 & 33 & 78.6 \\
\hline $\mathrm{Hh}$ & 5 & 50.0 & 16 & 33.3 & 9 & 21.4 \\
\hline $\mathrm{HH}$ & 0 & 0.0 & 1 & 2.1 & 0 & 0.0 \\
\hline Total & 10 & 100.0 & 48 & 100.0 & 42 & 100.0 \\
\hline
\end{tabular}

Hh genotype, but it should also be noted that the HH genotype was rare $(1 \%)$ in the test population, possibly suggesting a disadvantage of the $\mathrm{HH}$ genotype. However, the trend for the genotypes was not replicated in the allele frequencies, where increasing severity of periodontitis was not systematically reflected as a higher frequency of the $\mathrm{H}$ allele (Table 3). Due to the low frequency of the hh genotype, it is possible that an association can be demonstrated between the genotypes (or alleles) and severity of periodontitis by substantially increasing the sample size, and even then, the associations are likely to remain weak.

It is not surprising that a single polymorphism of a single gene, although an important BMD-associated one, was not by itself strongly associated with a multifactorial disease such as periodontitis.

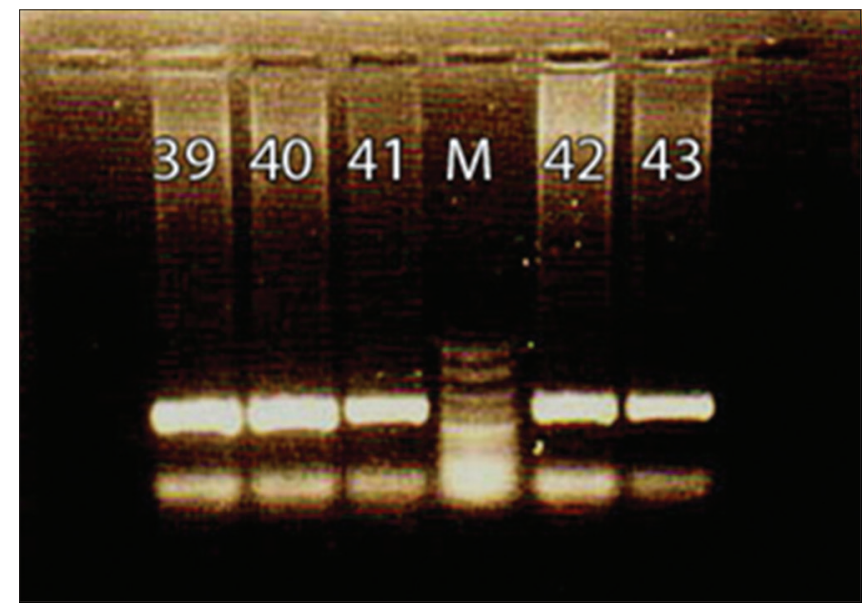

Fig. 1: Polymerase chain reaction product fragments of $253 \mathrm{bp}$; the bottom bands are primer dimers

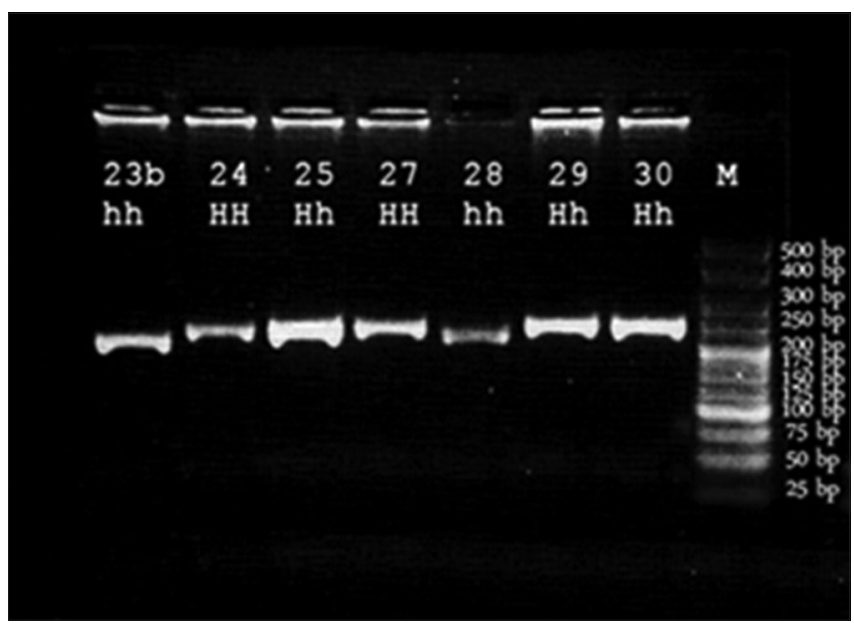

Fig. 2: Restriction fragment length polymorphism fragments: Lanes $23 \mathrm{~b}$ and 28 show mutant homozygous genotypes (hh, one lower thin band), lanes 24 and 27 show normal homozygous genotypes (HH, one thin upper band), and lanes 25, 29, and 30 show heterozygous genotypes ( $\mathrm{Hh}$, thick band)

Table 3: Distribution of alleles according to the severity of periodontitis

\begin{tabular}{|c|c|c|c|c|c|c|}
\hline \multirow[t]{2}{*}{ Severity } & \multicolumn{2}{|l|}{ Mild } & \multicolumn{2}{|c|}{ Moderate } & \multicolumn{2}{|l|}{ Severe } \\
\hline & Amount & Percentage & Amount & Percentage & Amount & Percentage \\
\hline \multicolumn{7}{|l|}{ Allele } \\
\hline $\mathrm{h}$ & 15 & 75.0 & 78 & 81.2 & 75 & 89.3 \\
\hline $\mathrm{H}$ & 5 & 25.0 & 18 & 18.8 & 9 & 10.7 \\
\hline Total & 20 & 100.0 & 96 & 100.0 & 84 & 100.0 \\
\hline
\end{tabular}


However, in combination with other OC polymorphisms and associated proteins (including RANK and RANKL), more significant associations could be explored in addition to increasing the sample size. Contradictory results regarding the association of OC with BMD are not uncommon [13-18]. In general, the tested populations show a roughly similar distribution of the OC C298T polymorphism, with the HH genotype being the least common polymorphism; [15-20] this was also the case in the present study. As a single polymorphism of a single gene may only show a weak association with a condition of interest, a stronger association has been explored using combinations of potential indicators [21-23].

\section{CONCLUSION}

The results showed a trend of an increasing frequency of the hh genotype (and h allele) of the OC C298T polymorphism with increasing severity of periodontitis in Indonesian male subjects. However, the trend was weak and not statistically significant for the tested sample population.

\section{ACKNOWLEDGMENTS}

Financial support from the University of Indonesia is gratefully appreciated (EIA, Grant number NKB-0249/UN2.R3.1/ HKP.05.00/2019).

\section{CONFLICTS OF INTEREST}

All authors have none to declare.

\section{REFERENCES}

1. Pradono P, Soemantri J, Soeharsono S. In: Ministry of Health, Republic of Indonesia, editor. Households' Health Survey (SKRT). Vol. 3. Jakarta: Depkes; 2004. p. 130-47.

2. Tadjoedin FM, Fitri AH, Kuswandani SO, Sulijaya B, Soeroso Y. The correlation between age and periodontal diseases. J Int Dent Med Res 2017; 10:327-32

3. Loe H, Morrison E. Epidemiology of periodontal disease. Contemp Periodontics 2003;106-16.

4. Newman MG, Takei H, Klokkevold PR, Carranza FA. Carranza's Clinical Periodontology. Amsterdam, Netherlands: Elsevier; 2006. p. 10.

5. Wiebe CB, Putnins EE. The periodontal disease classification system of the American Academy of Periodontology--an update. J Can Dent Assoc 2000;66:594-7.

6. Fedi PF, Vernino AR, Gray JL. The Periodontic Syllabus. Philadelphia, PA: Lippincott Willians and Wilkins; 2000.

7. Hoang QQ, Sicheri F, Howard AJ, Yang DS. Bone recognition mechanism of porcine osteocalcin from crystal structure. Nature 2003;425:977-80.

8. Dohi Y, Iki M, Ohgushi H, Gojo S, Tabata S, Kajita E, et al. A novel polymorphism in the promoter region for the human osteocalcin gene: The possibility of a correlation with bone mineral density in postmenopausal Japanese women. J Bone Miner Res 1998;13:1633-9.

9. Lerner UH. Inflammation-induced bone remodeling in periodontal disease and the influence of post-menopausal osteoporosis. J Dent Res 2006;85:596-607.

10. Ducy P, Desbois C, Boyce B, Pinero G, Story B, Dunstan C, et al. Increased bone formation in osteocalcin-deficient mice. Nature 1996;382:448-52.

11. Auerkari EI, Suryandari DA, Umami SS, Kusdhany LS, Siregar TW, Rahardjo TB, et al. Gene promoter polymorphism of RUNX2 and risk of osteoporosis in postmenopausal Indonesian women. SAGE Open Med 2014;2:2050312114531571. Available from: https://doi. org $/ 10.1177 / 2050312114531571$

12. Auerkari E, Suhartono A, Djamal N, Verisqa F, Suryandari D, Kusdhany L, et al. CRP and IL-1B gene polymorphisms and CRP in blood in periodontal disease. Open Dent J 2013;7:88-93.

13. Livshits G. Quantitative genetics of circulating molecules associated with bone metabolism: A review. J Musculoskelet Neuronal Interact 2006:6:47-61.

14. Deng HW, Recker RR. Gene mapping and identification for osteoporosis. J Musculoskelet Neurol Interact 2004;4:91-100.

15. Deng HW, Shen H, Xu FH, Deng HY, Conway T, Zhang HT, et al. Tests of linkage and/or association of genes for Vitamin D receptor, osteocalcin, and parathyroid hormone with bone mineral density. J Bone Miner Res 2002;17:678-86.

16. Xiao S, Huang Q, Kung AW. Genetics of osteoporosis in China. Int J Rheum Dis 2008;11:359-65.

17. Lei SF, Zhang YY, Deng FY, Liu MY, Liu XH, Zhou XG, et al. Bone mineral density and five prominent candidate genes in Chinese men: Associations, interaction effects and their implications. Maturitas 2005;51:199-206

18. Jiang DK, Xu FH, Liu MY, Chen XD, Li MX, Liu YJ, et al. No evidence of association of the osteocalcin gene HindIII polymorphism with bone mineral density in Chinese women. J Musculoskelet Neuronal Interact 2007;7:149-54.

19. Chen HY, Tsai HD, Chen WC, Wu JY, Tsai FJ, Tsai CH. Relation of polymorphism in the promotor region for the human osteocalcin gene to bone mineral density and occurrence of osteoporosis in postmenopausal Chinese women in Taiwan. J Clin Lab Anal 2001;15:251-5.

20. Xu H, Xiao W, Luo D, Liu YM, Zou L, Kuang HB. Association analysis of genetic polymorphisms and potential interaction of the osteocalcin (BGP) and ER-alpha genes with body mass index (BMI) in premenopausal Chinese women. Acta Pharmacol Sin 2010;31:455-60.

21. Lin GT, Tseng HF, Chang CK, Chuang LY, Liu CS, Yang CH, et al. SNP combinations in chromosome-wide genes are associated with bone mineral density in Taiwanese women. Chin J Physiol 2008;51:32-41.

22. Kim JG, Ku SY, Lee DO, Jee BC, Suh CS, Kim SH, et al. Relationship of osteocalcin and matrix Gla protein gene polymorphisms to serum osteocalcin levels and bone mineral density in postmenopausal Korean women. Menopause 2006;13:467-73.

23. Zhang J, Sun X, Xiao L, Xie C, Xuan D, Luo G. Gene polymorphisms and periodontitis. Periodontol 2000 2011;56:102-24. 